\title{
АКТИВНА ПОЗИЦЯ УКРАЇНСЬКОЇ МОЛОДІ ТА ПРОЗОРІСТЬ ВЛАДИ ЯК ОСНОВА РОЗБУДОВИ ГРОМАДЯНСЬКОГО СУСПІЛЬСТВА В УМОВАХ ДЕЦЕНТРАЛІЗАЦЇ̈
}

Kостева T. Б. канд. пед. наук, доцент, Інститут державного управління, Чорноморський національний університет імені Петра Могили, м. Миколаїв, Україна.

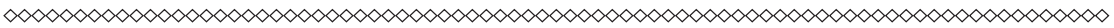

У статті розглянуто проблему позорості органів влади місиевого рівня, зниження активності громадян та пасивність молоді до прочесу контролю за органами влади. Дослідження вказує, щзо повна та актуальна інформація на веб-сайті та постійний контакт з жителями, підсилить позитивний імідж громад серед інших громад та усіх зацікавлених у співпраці сторін.

У статті піднімається питання прозорості у Миколаӥвському районі, де активісти натрапляють на значну кількість супротиву та закритості влади від громадян, пояснюючи це тим, щуо не варто витрачати час на інформування.

Сучасний світ вимагає кардинально відркитого, інформаційного підходу. Адже прочес децентралізаиії передбачає, щзо з часом, громади мають забезпечувати себе в усьому самостійно, мають настільки зараз розкрити в громадах потенціал, щуоб провідні ресурси були основою для самодостатності.

Розбудова громадянського суспільства, активне залучення до цุього проиесу молодого покоління є одним із найважливіших завдань суспільного розвитку в Украї ні на ї̈ иляху до успішної інтеграції в світову спільноту.

Ключові слова: громадянське суспільство, децентралізація, молодь, прозорість влади, сильна громада. 
Постановка проблеми у загальному вигляді. Однією 3 провідних умов сильної країни сьогодення $є$ формування громад як сильних, незалежних та стабільно економічно направлених. Така політика передбачена реформою децентралізації, яка у значній частині регіонів України, спричиняє великий конфлікт та непорозуміння того, що робити далі. Ідея реформи має глибокий ідейний позитивний намір. Та є значна проблема. Через те, що більшість керівників громад невзмозі використати всі позитивні напрями децентралізації у правильному руслі - це може призвести до того, що процес децентралізації в Україні стане нескінченим, значна частина реіонів втратить багато сіл.

Одже вбачаємо дві ключові проблеми сучасного управління в країни: відсутності принципу відкритості влади та пасивне ставлення молоді до політичних процесів, призводить до хаотичного правління українцями, як сільської, так і міської місцевості.

Аналіз останніх досліджень і публікацій. Західні й вітчизняні політологи знайшли принципово нові підходи до аналізу суспільних явищ, внаслідок чого політико-правова теорія збагатилася новими положеннями. Серед тих, хто в цей час активно займався та займається дослідженням проблем розвитку громадянського суспільства, можна виділити американських вчених Р. Нозіка, Т. Карозерса, Р. Патнема, Дж. Александера, Дж. Коена, Е. Арата, англійських дослідників Дж. Кіна, Е. Гелнера, німецьких вчених Ю. Габермаса, В. РеєзеШефера, В. Деттлінга, чехів Я. Тесаржа та В. Гавела, словацького вченого Р. Рошко, російських дослідників С. Перегудова, В. Хороса, В. Вітюка. Вітчизняні дослідники почали активно цікавитися цією темою ще $з$ середини 90-х років минулого століття, а після подій «помаранчевої революції» напрям громадянського суспільства взагалі став ледь не пріоритетним в українській політології та соціології. Серед останніх вагомих досліджень можна назвати здобутки таких авторів, як М. Михальченко, А. Колодій, І. Кресіна, С. Рябов, В. Барков, В. Бабкін, В. Бебік, В. Бортніков, А. Кудряченко, Ф. Рудич, М. Лациба, О. Вінніков, В. Селіванов, А. Сіленко, Г. Щедрова та ін. 
Виклад основного матеріалу дослідження. Актуальним є головне питання 3 чого починається сучасна сильна громада? Факторів успіху, звісно, чимало, однак саме принцип відкритості закладає основу для розвитку ОТГ (об’єднаних територіальних громад) в усіх сферах. Найпростіший спосіб продемонструвати прозорість вашої ОТГ - докладно розповісти про неї на офіційному сайті, який часто $є$ точкою входу при знайомстві з громадою. Повна та актуальна інформація на вебсайті підсилить позитивний імідж громади серед інших громад та усіх зацікавлених у співпраці сторін.

Піднімаючи питання прозорості у Миколаївському районі, активісти натрапляють на значну кількість супротиву та закритості влади від громадян, пояснюючи це тим, що не варто витрачати час на інформування, треба працювати. Але, сучасний світ вимагає іншого підходу. Адже процес децентралізації передбачає, що 3 часом, громади мають забезпечувати себе в усьому самостійно, мають настільки зараз розкрити в громадах потенціал, щоб провідний ресурс, такий як наприклад, людський капітал, земля, новостворенні підприємства, малий бізнес, робочі місця для населення, у майбутньому були самодостатніми та вміли самостійно себе фінансувати у провідних напрямах.

Тож, для кого важлива така прозорість?:

- для мешканців. Прозорий підхід до оприлюднення інформації про громаду заощадить чимало часу мешканцям. Громадянам не треба годинами вишукувати потрібні контакти чи документ на сайті, адже все доступно у структурованій формі у кілька кліків. Такий підхід сформує довіру до керівництва громади та продемонструє мешканцям, що для них працює чесна та відкрита команда.

- для місцевого бізнесу. Локальним підприємцям важливо знати, які можливості розвитку відкриваються для них у громаді. Чи можна запропонувати свої товари чи послуги для тендеру; 3 ким комунікувати щодо відкриття нової торговельної точки; На всі ці питання має бути легко знайти відповідь на сайті.

- для потенційних інвесторів. Інвестори прискіпливо оцінюють варіанти вкладення власних коштів, тому важливо дотримуватися принципу прозорості й у оприлюдненні даних про всі бізнес- 
можливості громади. Чесна та актуальна інформація про громаду запорука зацікавленості інвестора та налагодження вдалих подальших партнерств.

Важливим процесом прозорості влади $є$ відкритість та професіоналізм роботи комунальних підприємств, які створюються на території громади, аби забезпечити покращення певних умов життя та забезпечення їх стабільності.

Комунальні підприємства забезпечують громади різними видами послуг - це й благоустрій, і житлово-комунальні послуги (водопостачання та водовідведення, теплопостачання, вивезення сміття, ритуальні послуги) тощо.

Держава дала можливість прослідкувати переміщення грошей 3 однієї кишені в іншу за допомогою сайту spending.gov.ua. Значна частина комунальних підприємств, а особливо в сільських громадах, $\epsilon$ збитковими i не можуть похвалитися позитивною фінансовою рентабельністю та спроможністю. Особливої уваги заслуговує питання добросовісного розрахунку за спожиті комунальні послуги клієнтами (населенням, організаціями та підприємствами ОТГ), особливо у сфері водопостачання/водовідведення та вивезення сміття.

На думку експертів DOBRE, такі проблеми комунальних підприємств виникають здебільшого через непоінформованість громади та непрозору діяльність самих підприємств, незалученість громадян до управління діяльністю і як наслідок - нерозуміння, для чого і на яких засадах працює комунальне підприємство [1].

3 розвитком інформаційних технологій, сайти в мережі Інтернет стали одним з основних джерел інформації для кожної людини. Оприлюднення відповідних даних та інформації на сайті органів місцевого самоврядування сприяють відкритості самого органу та поінформованості населення щодо будь-якого питання або можливості.

Але, враховуючи, що немає єдиних вимог щодо інформації, яка має міститись на сайтах місцевих рад, окрім Постанови КМУ №835 «Про затвердження Положення про набори даних, які підлягають оприлюдненню у формі відкритих даних» від 21.10.2015 р., сайти 
кожної громади мають досить різне наповнення. Або ж сайт взагалі відсутній.

Тож, якщо влада не виконує закони і постанови, до громадського контролю мають активно залучатися самі мешканці громади 3 вимогою надавати пояснення, адже саме громада є провідною владою, яка надала можливість іншим спрямовувати їх бажання у русло керівництва та розпорядження. I звісно, головний напрям таких контрольних заходів покладається на молоде покоління.

Крім традиційних проблем місцевого самоврядування в період децентралізації (в цілому): таких як відсутність належного ресурсного забезпечення місцевого самоврядування - в реаліях сьогодення - недостатнє фінансове забезпечення виконання власних повноважень, так само і делегованих, які з часом стають проблемами місцевих бюджетів; нечітким законодавчим врегулюванням служби в органах місцевого самоврядування; достатньо занизьким рівнем впровадження електронного врядування, забезпечення адміністративних та соціальних послуг населенню, неефективним управлінням комунальним господарством, комплексним соціально-економічним розвитком населених пунктів, підготовкою, перепідготовкою та підвищенням кваліфікації посадових осіб місцевого самоврядування та депутатів місцевих рад

Окрім цього, уряд поставив за мету у 2020 році завершити процес децентралізації (хоча сам процес полягає не тільки в автоматичном приєднанні однієї громади до іншої), ми маємо низку проблем нормативних актів щодо:

- становлення повних і виключних повноважень органів місцевого самоврядування базового, районного та обласного рівнів. Такі повноваження не можуть скасовуватися чи обмежуватися органами державної влади будь-якого рівня, якщо це не передбачено законом;

- $\quad$ запровадження прозорих механізмів адміністративного нагляду органів державної влади за органами місцевого самоврядування, які не суперечитимуть принципам Свропейської хартії місцевого самоврядування і не блокуватимуть діяльність органів місцевого самоврядування у разі виникнення спірних питань; 
- $\quad$ закріплення за місцевими бюджетами стабільних джерел доходів та розширення доходної бази місцевих бюджетів;

- $\quad$ розмежування повноважень між органами виконавчої влади та органами місцевого самоврядування різних рівнів з метою забезпечення найбільш ефективного їх виконання;

- $\quad$ питання реорганізації органів місцевого самоврядування в новоутворенних громадах і райдержадміністрації в нових районах, правонаступництва комунального і державного майна, бюджетних ресурсів, прав та інших зобов'язань;

- питання утворення та ліквідації райдержадміністрацій у зв’язку з утворенням (ліквідацією) районів.

Сьогодні все це є умовним, на рівні законопроектів, і як ніколи такі прогалини у законодавстві відчув на практиці Миколаївський район.

Виходячи з аналізу діяльності органів влади Миколаївського району, взаємозв'язку влади з громадськістю та участю молоді в соціально-політичних процесах, важко назвати країну правовою державою.

Сьогодні в Україні все починається і закінчується фінсовими аспектами. I коли цей ресурс закінчиться у громаді, і доведеться все скорочувати, оптимізувати і закривати, тоді кожен почне шукати винних. Нажаль жителі громад не прагнуть до аналізу.

Тому, робота місцевої влади вкрай потребує прозорості. Тільки тоді, коли громада буде знати про кожну копійку, яка була на неї витрачена, тільки тоді буде довіра до влади.

Дороги, фонтани, квіти, догляд за квітами, закупівля канцелярських товарів на десятки тисяч гривень, ремонтні роботи і прикраси в парку, на зупинці чи коло будинку, за рахунок місцевого бюджету - кожна дія має свою ціну і має бути пояснена. Має бути пояснення і оприлюднення діяльності комунальних підприємств i підрозділів місцевої влади. Через них також йдуть десятки тисяч гривень, як державних так і коштів місцевих бюджетів.

Отже, переваги дотримання та виконання таких вимог надасть наступне:

- довіра до влади у людей, у яких були сумніви щодо прозорості, зросте в рази; 
- значно зросте ефективність у використанні коштів;

- буде значно раціонально використані кошти громади.

Один із найавторитетніших сучасних дослідників популізму нідерландський політолог Кас Мудде каже, що сучасний популізм базується на двох твердженнях, саме з них він черпає свою силу [2]:

перше: суспільство $є$ жорстко поділеним на дві ворогуючі групи - «чесний народ» і «корумповані еліти».

друге: політики мають виражати «волю народу», натомість вони $є$ закритою кастою, яка працює винятково у своїх інтересах.

Згідно тверджень Кас Мудде популіст має наступний портрет:

популісти завжди гуртуються довкола лідера;

цей лідер обов'язково протиставляє себе корумпованій еліті, неефективній владі, хоча сам може бути владою, і називає себе виразником інтересів народу;

він надає перевагу «прямому спілкуванню з народом», уникаючи посередництва професійних журналістів. Надає про себе, свою діяльність вкрай обмежену, дозовану інформацію;

популісти промовляють від імені скривдженого народу, але при цьому вони не хочуть, щоб їх виборці змінювалися на краще. Це відрізняє сучасних популістів від, скажімо, соціалістів початку 20го століття, які хотіли, щоби пролетаріат став освіченішим, краще підготовленим до життя. Популісти кажуть, що народ і так ідеальний - то влада погана;

популіст звертається здебільшого до «відчуттів», а не «фактів» (голосуй серцем);

популісти апелюють до «прямої демократії». «Народ мене вибрав. Крапка» [2].

Популізм - це насамперед стверджувати, що проблеми або вирішуватимуться самі собою або за допомогою одного простого рішення, замість того, щоб зображувати поступовий алгоритм дій, наголощує аналітик Українського інституту майбутнього Ігор Тишкевич [3].

Фокусуючись на реальних проблемах популісти використовують частіше емоційні, ніж раціональні аргументи, застосовуючи риторику звинувачень та розпалювання протиріч. Вони не схильні го- 
ворити з публікою про проблеми з позиції їхнього вирішення. Критика чогось або когось спрямовується саме на ескалацію протиріч.

У кожній громаді має бути План заходів 3 підготовки проєкту бюджету на 2021 рік, в якому мають бути викладені основні етапи його підготовки, в тому числі, у зв'язку зі створенням, приєднанням до ОТГ сільських рад, має бути тісна співпраця між ОТГ та сільрадами, залучена громадськість до процесу складання проєкту бюджету (проведення громадських слухань, консультацій з громадськістю тощо).

Ще $з$ радянських часів органи місцевої влади не те, що тримали в таємниці процес формування бюджету, вони просто тихенько в ручному режимі його ділили. Але й люди не дуже то і цікавились бюджетним процесом.

Але на сьогодні ці часи вкрай неактуальні, адже тепер влада передана на місця, тому і громадянам, особливо молоді, набагато ближче до процесу контрою за органами влади. Люди мають знати, які доходи і видатки плануються на наступний рік. Це їх гроші, їх податки, їх життя. Саме тому, активна позиція молоді та громади в цілому - це крок до ефективності розвиту громади, в том учислі за одним 3 найголовнішим важелем напряму дороги громад - бюджету.

Основними завданнями бюджету громади за участю молоді, жителів,має бути наступне:

- активізація підприємницького потенціалу, підвищення податкоспроможності;

- підвищення результативності та ефективності бюджетних видатків;

- посилення бюджетної дисципліни та контролю за витратами бюджету;

- підтримка економічного зростання, підвищення рівня прозорості та раціональності бюджетного процесу, зміцнення фінансово-економічної самостійності бюджету громади.

Гуманітарні питання сьогодні настільки складні, що у більшості випадків їх замовчують. Молоді як ніколи, зараз потрібно бути раціональною, критичною до влади і думати про мабутнє.

Аби допомогти громадам демонструвати прозорість, громадська організація SocialBoost, партнер із технологічного компоненту 
Програми DOBRE, створила Dosvit - платформу, що дозволяє ОTГ створювати власні сайти за усіма сучасними IT-канонами. Платформа також допомагає громадам швидко налаштовувати усі базові додатки, що забезпечують їі прозорість та відкритість.

Крім того, важливим додатком, що має й просвітницький характер, є «Симулятор бюджету». Він пояснює складні цифри та дає зрозуміти, як використовуються податкові гривні громадян. Додаток - це інтеграція платформи Dosvit з порталом Ціна держави (CASE Україна). Завдяки такому інструменту усі охочі зможуть аналізувати, як формуються доходи громади, моделювати бюджет у простій ігровій формі, а також пропонувати нові актуальні для ОТГ проекти. Наразі платформою Dosvit користуються громади Програми DOBRE у семи областях: Дніпропетровській, Івано-Франківській, Харківській, Херсонській, Кіровоградській, Миколаївській та Тернопільській.

Важливою для прозорості влади та активності населення є тема культури. Нажаль, в Миколаївському районі органи місцевої влади вирішили, що залучення до культурних заходів всіх верств населення зовсім не обов'язкове. Достатньо раз у рік зробити показові свята, такі як День села (а краще двічі на рік, вдруге, чомусь, припадає саме під вибори), добряче нагодувати та напоїти людей, розказати «про світле майбутнє» і все - досить культури.

В сільських місцевостях сучасних децентралізованих територіальних громадах молодь і не здогадується, що в неї може бути інше життя, повне енергії та творчості. І це, сповнене життя, повинні надати їм дорослі. Але байдужість до внесків у такий капітал як культура дітей та молоді та контролю цього процесу з боку влади не надає перспектив та можливості до змін майбутніх поколінь.

Щодо оцінки молоддю наскільки об'єднання громад впливає на становище молоді, то 12,7 \% молоді, яка проживає в об'єднаних територіальних громадах, відчули зміни, пов'язані зі створенням та розбудовою об'єднаної територіальної громади, а саме: покращення соціальної інфраструктури своїх населених пунктів та підвищення якості культурно-просвітницьких заходів. За результатами опитування 2018 року вже 23,0 \% опитаної молоді мешкали в населених 
пунктах, що входили до об'єднаних територіальних громад. У процесі об'єднання територіальних громад 24,4 \% молодих людей готові брати активну участь [4]

Якщо в 2017 році на гіпотетичне запитання яким чином молодь може брати участь у діяльності об’єднаної територіальної громади, більшість опитаної молоді визнала можливість участі молоді в розробці і реалізації молодіжних проектів та ініціатив $(76,6$ \%), створенні молодіжних ініціативних груп або організацій (76,2%), громадському контролі (73,3 \%), у громадських зборах та слуханнях (71,6 \%), у розробці та реалізації стратегій і проектів розвитку ОТГ $(69,3 \%)$, представництві у виконавчих органах ОТГ $(68,5 \%)$ та в громадських радах (66,9 \%). Значно менший відсоток молодих людей долучається до громадського життя. Так, на запитання анкети 2018 року «Як Ви долучаєтесь та бачите свою участь у життєдіяльності громади?» у першу чергу молоді люди назвали голосування на виборах (41,9 \%), а також участь у загальних зборах $(29,1 \%)$ та участь у роботі по благоустрою $(21,4$ \%) (рис.1).


Рис. 1. Участь молоді у житті ромади за віковою характеристикою.

Найбільш нагальними проблемами розвитку територіальних громад, що є актуальними зараз і будуть важливими через три роки, молоді люди назвали насамперед таку актуальну інфраструктурну проблематику, як відкриття/ облаштування/ремонт/реконструк- 
ція доріг та тротуарів (73,1 \% та 37,1 \% відповідно), будівництво шкіл (35,1 \% та 29,0 \% відповідно), лікарень/поліклінік/амбулаторій (34,0 \% та 23,6 \% відповідно) та місць відпочинку у громаді (34,0 \% та $35,7 \%$ відповідно), а також дитячих садочків (30,0 \% та 23,6 \% відповідно) [5].

Однією з форм участі молоді в управлінні державними справами, залучення до ухвалення рішень, що стосуються молодіжних питань, є участь у роботі консультативно-дорадчих органів: молодіжних рад, колегій, парламентів, координаційних рад з питань національно-патріотичного виховання молоді тощо.

Участь молоді в процесах управління державними справами та розвитком громади неможлива без належного розвитку молодіжної інфраструктури. Молодіжні центри як осередки неформальної освіти та формування активної громадянської позиції серед молоді є тими закладами, які інформують, консультують та залучають молодь до участі в суспільному житті громади. На сьогодні розвиток мережі молодіжних центрів є пріоритетом молодіжної політики в Україні. Напрями їхньої роботи формуються відповідно до потреб та інтересів молодих людей конкретного населеного пункту. Молодь вважає, що діяльність молодіжного центру має бути спрямована в першу чергу на організацію спортивних (42,3 \%) та розважальних $(37,2$ \%) заходів, надання юридичної $(35,7$ \%) та інформаційної $(33,5 \%)$ підтримки.

Також молодь формує запит до молодіжних центрів щодо профоріснтаційних заходів (32,3\%), роботи 3 цільовими групами молоді (31,2 \%), консультаційних послуг психологів (30,0 \%) та надання культурно-мистецьких послуг (20,8 \%). Ураховуючи результати соціологічного дослідження «Молодь України - 2018», необхідним $\epsilon$ посилення інформаційної кампанії з приводу можливостей молодіжних центрів, їх функціонального наповнення та мети діяльності, де на перше місце виноситься сприяння у соціалізації та самореалізації молоді.

Для активізації та підтримки участі молоді, місцева, регіональна, державна молодіжна політика має бути орієнтованою на розв’язання таких питань як: 
- забезпечення умов для участі молоді та молодіжного громадського контролю шляхом створення молодіжних консультативно-дорадчих органів;

- проведення заходів і реалізація програм та проектів щодо інформування, консультування, надання рекомендацій та роз'яснень молодим людям стосовно участі в ухваленні та реалізації рішень, що стосуються молодіжних питань та реформування різних сфер життя;

- адміністративне забезпечення молодіжної роботи, що передбачає формування структурних підрозділів молодіжної сфери та професійне кадрове забезпечення їх діяльності;

- формування молодіжної інфраструктури, а саме: розвиток мережі молодіжних центрів/молодіжних просторів, що створює умови об’єднання соціально активної молоді;

- запровадження механізмів інституційної підтримки розвитку і діяльності громадських об'єднань, залучення інститутів громадянського суспільства до реалізації молодіжної політики [6].

Молодь є більш вільною у виборі направленості розвитку і налаштованою на нове та прогресивне. 3 метою формування сприятливих умов для активізації громадянської та соціально-політичної активності молоді необхідно:

- активізувати роботу молодіжних та дитячих громадських об'єднань, спрямування їхньої діяльності на досягнення конкретних результатів та об'єднання активної молоді;

- організувати співпрацю українських та міжнародних громадських об'єднань із запровадження моделей залучення молоді до вирішення місцевих проблем, розвитку волонтерства, соціального підприємництва;

- розвивати умови участі молодих громадян у формуванні та реалізації державної молодіжної політики .

Висновки. Важливою умовою для здатності молодого покоління сприймати цінності громадянського суспільства, розуміти необхідність його становлення та розвитку, є формування в свідомості молоді переконання щодо необхідності становлення демократичного ладу, досягнення необхідного рівня громадянської культури, 
формування навичок та досвіду суб'єктності в демократизації системи державно-суспільних відносин. Провідним фактором довіри громадян, а особливо молодого покоління до влади є іï всебічна прозорість. Задля формування та розвитку такої прозорості, молодь має продемонструвати справжню громадянськість та стати провідним контролером оранів влади.

Стаття надійшла до редколегії: 15.01.21

\section{ACTIVE POSITION OF UKRAINIAN YOUTH AND TRANSPARENCY OF GOVERNMENT AS A BASIS FOR BUILDING CIVIL SOCIETY IN CONDITIONS OF DECENTRALIZATION}

Tetiana Kostieva, $\mathrm{PhD}$ in Pedagogy, Associate professor Black Sea National University of Petro Mohyla, Mykolaiv, Ukraine.

The article considers the problem of shame of local authorities, reducing the activity of citizens and the passivity of young people to the process of control over the authorities. The study indicates that complete and up-to-date information on the website and constant contact with residents will strengthen the positive image of communities among other communities and all stakeholders.

The article raises the issue of transparency in the Mykolaiv district, where activists encounter a significant amount of resistance and secrecy of the authorities from citizens, explaining this by the fact that it is not worth spending time informing.

The modern world requires a radically open, informational approach. After all, the process of decentralization implies that over time, communities must provide for themselves in everything, they must now so open the potential in communities that the leading resources are the basis for self-sufficiency.

The development of civil society and the active involvement of the younger generation in this process is one of the most important tasks of 
social development in Ukraine on its way to successful integration into the world community.

Raising questions of transparency in the Nikolaev region, activists come across a considerable amount of resistance and secrecy of the power from citizens, explaining it that it is not necessary to spend time for informing, it is necessary to work. But, the modern world requires a different approach.

After all, the process of decentralization implies that over time, communities must provide for themselves in everything, must now so open the potential in communities that the leading resource, such as human capital, land, start-ups, small businesses, jobs for the population, in in the future to be self-sufficient and be able to finance themselves in leading areas.

Thus, the leading factor in the trust of citizens, and especially the younger generation, in power is its comprehensive transparency. In order to form and develop such transparency, young people must demonstrate true citizenship and become the leading control of the authorities.

Key words: civil society, decentralization, youth, transparency of government, strong community.

\section{Received: 15.01.21}

\section{References}

1. Detsentraliatsiia: mizhnarodne poiednannia [Decentralization: an international association]. donors.decentralization.gov.ua. Retrieved from https:// donors.decentralization.gov.ua/project/dobre [in Ukrainian].

2. Chomu populizm vyhraie [Why populism wins]. zbruc.eu. Retrieved from https://zbruc.eu/node/90935 [in Ukrainian].

3. Populizm u sviti i vybory [Populism in the world and elections]. $w w w$. radiosvoboda.org. Retrieved from https://www.radiosvoboda.org/a/29759648. html [in Ukrainian].

4. «Molod Ukrainy» ["Youth of Ukraine»]. (2017). Nezalezhnyi tsentr sotsialnykh nauk «OMEHA» [in Ukrainian].

5. «Molod Ukrainy» [«Youth of Ukraine»]. (2018). LLS «Persha reitynhova systema» [in Ukrainian].

6. Zhdanov I.O. \& Yarema O.Iu. (Ed.). (2018). Uchast molodi u protsesakh derzhavnoi reformy. Richnyi zvit Prezydentu Ukrainy, Verkhovnii Radi Ukrainy, 
Kabinetu Ministriv Ukrainy pro stanovyshche molodi v Ukraini (za pidsumkamy 2017 roku) [Participation of youth in the processes of state reform. Annual report of the President of Ukraine, the Verkhovna Rada of Ukraine, the Cabinet of Ministers of Ukraine on the youth population in Ukraine (following the results of 2017)]. Derzh. Instytut simeinoi ta molodizhnoi polityky. Kyiv: Derzhavne pidpryiemstvo «Redaktsiinyi visnyk Ofitsiinoho visnyka Prezydenta Ukrainy» [in Ukrainian].

7. Konstytutsiia Ukrainy [Constitution of Ukraine].zakon1.rada.gov.ua. Retrieved from http://zakon1.rada.gov.ua/cgi-bin/laws/main.cgi?user [in Ukrainian].

8. Rozporiadzhennia Kabinetu Ministriv Ukrainy Pro skhvalennia Kontseptsii reformuvannia mistsevoho samovriaduvannia ta terytorialnoi orhanizatsii vlady v Ukraini: vid 1 kvitnia 2014 r. No 333-r. [Order of the Cabinet of Ministers of Ukraine On understanding the Concept of reforming local self-government and territorial organization of power in Ukraine: of April 1, 2014 No 333-r.]. zakon4.rada.gov.ua. Retrieved from http://zakon4.rada.gov. ua/laws/show/333-2014-r [in Ukrainian].

9. Yevropeiska khartiia mistsevoho samovriaduvannia, Strasburh, 15 zhovtnia 1985 roku (Khartiiu ratyfikovano Zakonom No452/97-VR vid 15.07.97), Data pidpysannia: 6 lystopada 1996 r. [European Charter of Local Self-Government, Strasbourg, 15 October 1985 (Charter ratified by Law No452 / 97-VR of 15.07.97), Date of signature: 6 November 1996]. zakon.rada.gov.ua. Retrieved from http:// zakon.rada.gov.ua [in Ukrainian].

10. Aznar, M. (2005). Frantsuzkyi pryklad rehionalizatsii, detsentralizatsii ta dekontsentratsii Orhanizatsiia rehionalnoi ta mistsevoi vlady: dosvid derzhav-chleniv Yevropeiskoho Soiuzu [French example of regionalization, decentralization and deconcentration Organization of regional and local government: the experience of member states of the European Union]. Spetsialne dopovnene vydannia Ukrainsko-Yevropeiskoho Zhurnalu z Mizhnarodnoho ta Porivnialnoho prava - Special supplement to the Ukrainian-European Journal of International and Comparative Law, (pp. 38-49) [in Ukrainian].

11. Andriievskyi, T. (2014). Detsentralizatsiia - zaporuka protsvitannia [Decentralization - the key to prosperity]. Visnyk ministerstva dokhodiv i zboriv Ukrainy - Bulletin of the Ministry of Revenue and Duties of Ukraine, 36, (pp. 46-47) [in Ukrainian].

12. Babinova, O.O. (2011). Derzhavna rehionalna polityka i rehionalnyi rozvytok: suchasni realii Ukrainy ta yevropeiskyi dosvid [State regional policy and regional development: modern realities of Ukraine and European experience]. K.: Feniks [in Ukrainian]. 
13. Baimuratov, M. (2015). Detsentralizatsiia ta kompetentsiia mistsevoho samovriaduvannia v Ukraini [Decentralization and competence of local government in Ukraine]. Viche - Viche, 12, (pp. 14-17) [in Ukrainian].

14. Batanov, O. (2015). Rozvytok konstytutsiinoho zakonodavstva pro status terytorialnykh hromad $\mathrm{v}$ Ukraini: doktrynalni ta prykladni aspekty [Development of constitutional legislation on the status of territorial communities in Ukraine: doctrinal and applied aspects]. Viche - Viche, 12, (pp. 18-22) [in Ukrainian].

15. Barvitskyi, V. (2006). U poshukakh shliakhiv formuvannia diiezdatnykh terytorialnykh hromad: mizhnarodnyi dosvid [In search of ways to form viable territorial communities: international experience]. Problemy detsentralizatsii: natsionalnyi ta mizhnarodnyi dosvid. Zbirnyk materialiv ta dokumentiv Problems of decentralization: national and international experience. Collection of materials and documents. K.: Atika-N [in Ukrainian].

16. Bezsmertnyi, R. (2005). Samovriaduvannia. Konstytutsiina model i problemy povnotsinnoho funktsionuvannia [Self-government. Constitutional model and problems of full functioning]. Viche - Viche, 11, (pp. 45-57) [in Ukrainian].

\section{Відомості про авторів / Information about the Authors}

Костсва Тетяна Богданівна: Чорноморський національний університет імені Петра Могили вул. 68 Десантників 10, Миколаїв, 54003, Україна.

Tetiana Kostieva: Black Sea National University of Petro Mohyla: 68 Desantnykiv str. 10, Mykolaiv, 54003, Ukraine.

\section{ORCID.ORG/ 0000-0002-6455-4382}

\section{E-mail: tetyana910@com.ua}

